\title{
A RANGE
}

\section{CONDITION}

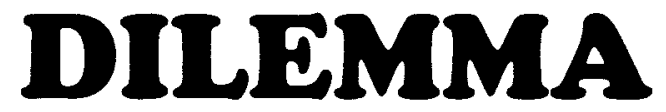

\section{Michael G. Willoughby and Michael J. Alexander}

In

the late 1800's livestock grazing was unregulated along the eastern slopes of the Rocky Mountains in Alberta. To protect the Saskatchewan River basin watershed the Rocky Mountains Forest Reserve (RMFR) was established in 1910. Grazing by domestic animals was prohibited. However, by 1913 grazing by livestock was recognized as a useful tool to limit forage accumulation and assist in reducing a potential fire hazard. Inadequate management policies and funding, caused water quality to continue to deteriorate because of fire and localized overgrazing. To examine the overgrazing concerns in the Rocky Mountains Forest Reserve, Land and Forest Service established the Rangeland Reference Area Program in 1949. The objectives were to assess range condition and monitor range trend on grasslands within the boundaries of the RMFR (Hanson 1975).

To date forty-five fenced exclosures have been established in the RMFR, some dating back to 1953. These exclosures include permanently marked grazed and ungrazed transects. Species composition data has been recorded since their establishment. Recent analysis indicates that the vegetation moves through a number of vegetation states and the process closely follows the "state and threshold" model of succession (Laycock 1991). This created a dilemma on how the condition of these rangelands should be assessed because condition ratings for Alberta rangelands have used the old "linear range condition" model (Wroe et al. 1988).

To examine the vegetation changes at the various reference areas over-time a combination of both ordination (DECORANA) (Gauch 1982) and cluster analysis (SAS) were used to group the inside and outside transects of different years. The groupings from cluster analysis were overlain on the site ordination and years with similar species composition were grouped into community types.

Mean grazing pressure for each year was assessed by comparing annual utilization to the rated carrying capacity of the allotment. Total yearly AUM (Animal Unit Months) usage from the inception of the allotment was divided by the calculated carrying capacity (AUM) and multiplied by 100. For example a number of 100 would indicate proper utilization.

\section{Historic grazing pressure}

Range use has averaged over $154 \%$ of calculated carrying capacity since 1947 when records were first kept at the Castle River site. Range use around the reference area has averaged 175\% of calculated carrying capacity from 1940 through the 1970 's. Use declined somewhat during the 1980 's averaging $127 \%$ of calculated carrying capacity. Since 1990 use has declined to $67 \%$ of calculated carrying capacity. 


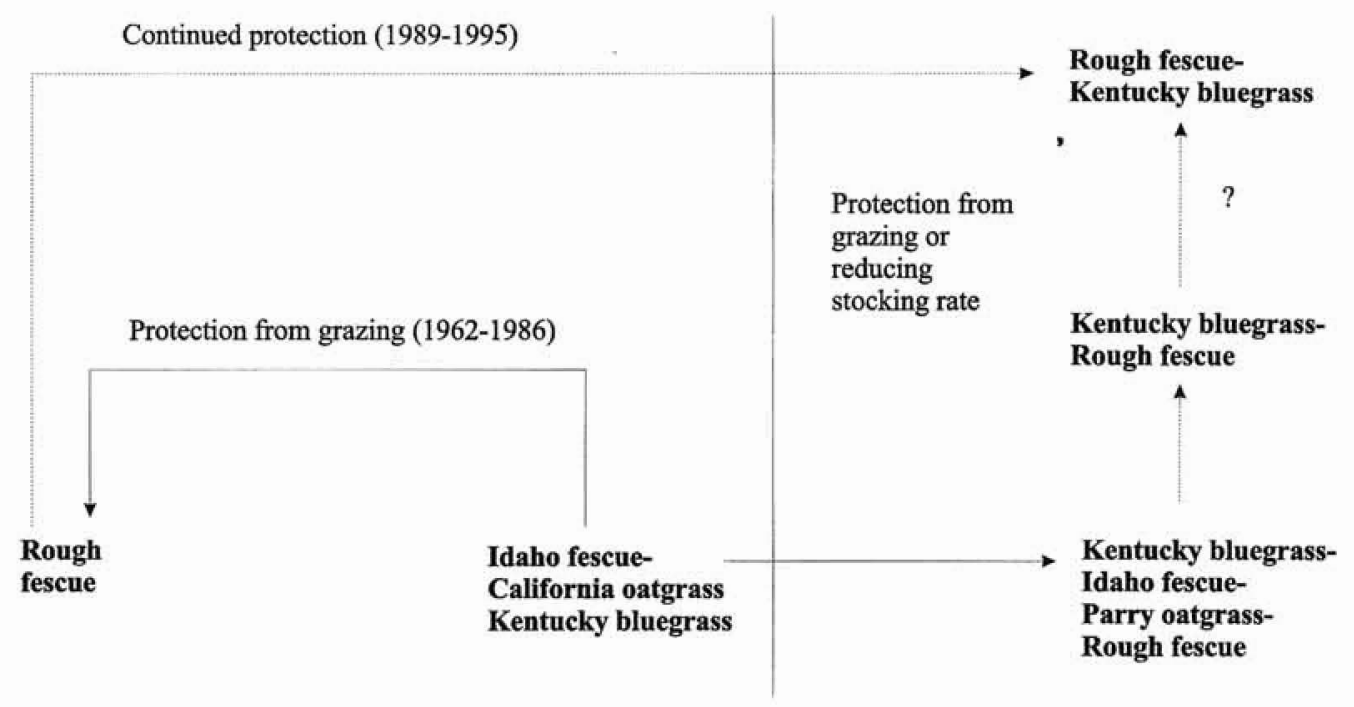

Increasing grazing pressure

Increasing duration of time

Fig. 1. Successional changes in the presence and absence of grazing disturbance at the Castle River Rangeland Reference Area.

\section{Plant community ecology}

The rangeland reference area has been represented by 3 community types since it was established in 1953 ( Figure 1). When the site was first established the inside and outside transects were represented by the Idaho fescue-California oatgrass community type. When the site was protected from grazing for 24 years it succeeded to a rough fescue dominated community type. Moss and Campbell, and Willoughby found that rough fescue grows almost to the exclusion of other plants in the absence of disturbance. Moss and Campbell also found that rough fescue declined and Parry oatgrass and Idaho fescue increased with increased grazing pressure indicating that the Idaho fescue-California oatgrass dominated community type which dominated the site in 1962, to be a grazing disclimax community. Since 1989, the undisturbed inside transect at the site has been invaded by Kentucky bluegrass from outside the exclosure and the transect appears to be undergoing succession to a Rough fescue-Kentucky bluegrass dominated community type.

The continued heavy grazing pressure at the reference area from 1953 to 1990 , has allowed Kentucky bluegrass to become dominant on the outside grazed transect to form a Kentucky bluegrass-Idaho fescue-Rough fescue community. Moss and Campbell, Looman and Willms et al., all found that long-term heavy grazing pressure leads to a decline in rough fescue and an increase in Kentucky bluegrass. Since 1990 the grazing pressure has declined to about two thirds of the calculated carrying capacity. During this time rough fescue has increased in cover and the transect appears to be succeeding to a Kentucky bluegrass-Rough fescue dominated community type.

The successional sequences for the Castle River Rangeland Reference Area are outlined in Figure 1. Protection from grazing on the Idaho fescue-California oatgrass community type in
1962 allowed rough fescue to increase, to form the rough fescue dominated community type in 1986. Invasion by Kentucky bluegrass since 1989 appears to be causing the inside transects to succeed to a Rough fescue-Kentucky bluegrass dominated community type. Continued grazing pressure on the outside transect has allowed Kentucky bluegrass to dominate the site and the reduction in grazing pressure in the 1990 's appears to be allowing rough fescue to increase. The outside transect now appears to be succeeding to a Kentucky bluegrass-Rough fescue dominated community type.

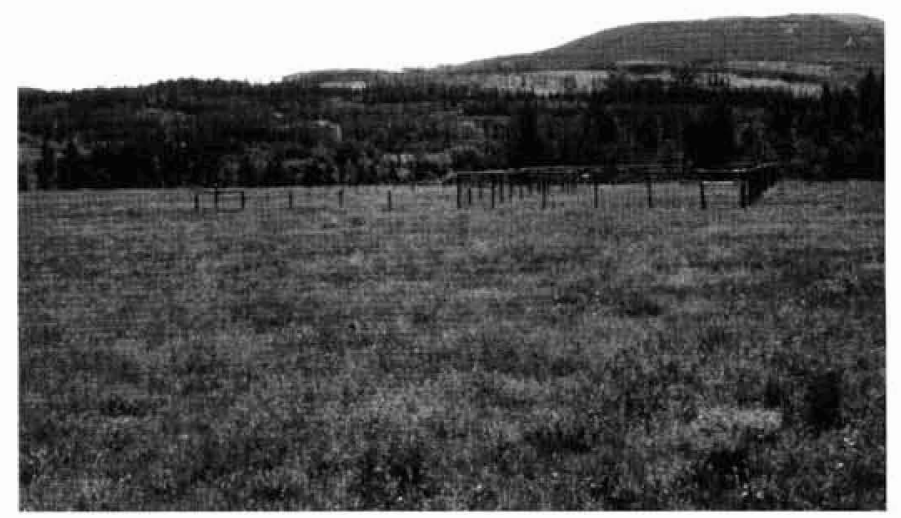

The grazed transect at the Castle River Rangeland Reference Area was established in 1953 and the ungrazed transect was established in 1962. This reference area has been subjected to intense grazing pressure since 1947 when records were first kept. 
This model implies that the grassland species composition moves to the point of stabilization with plant species that have invaded rather than succeed back to the original vegetation

\section{Range condition}

Traditionally, range condition in Alberta, has been defined by comparing species present with species of the climax community (Dyksterhuis 1949). This climax range condition model suggests that vegetation will be directional, predictable and revert back to the original rough fescue dominated predisturbance plant community in time. This concept appears to be applicable to this reference area up to the point in time before Kentucky bluegrass becomes a significant component of the community. When a Idaho fescue-California oatgrass community type is protected from grazing it appears to succeed back to a rough fescue dominated grassland. Consequently, the inside grazed transect would have been in good to excellent condition in 1986. However, once Kentucky bluegrass invades the community the traditional range condition model does not apply and the vegetation dynamics closely follow the state and threshold model. This model implies that the grassland species composition moves to the point of stabilization with plant species that have invaded rather than succeed back to the original vegetation. It appears once Kentucky bluegrass becomes established it continues to remain co-dominant with rough fescue in the absence of disturbance. It seems that both models apply to the vegetation dynamics of this site.

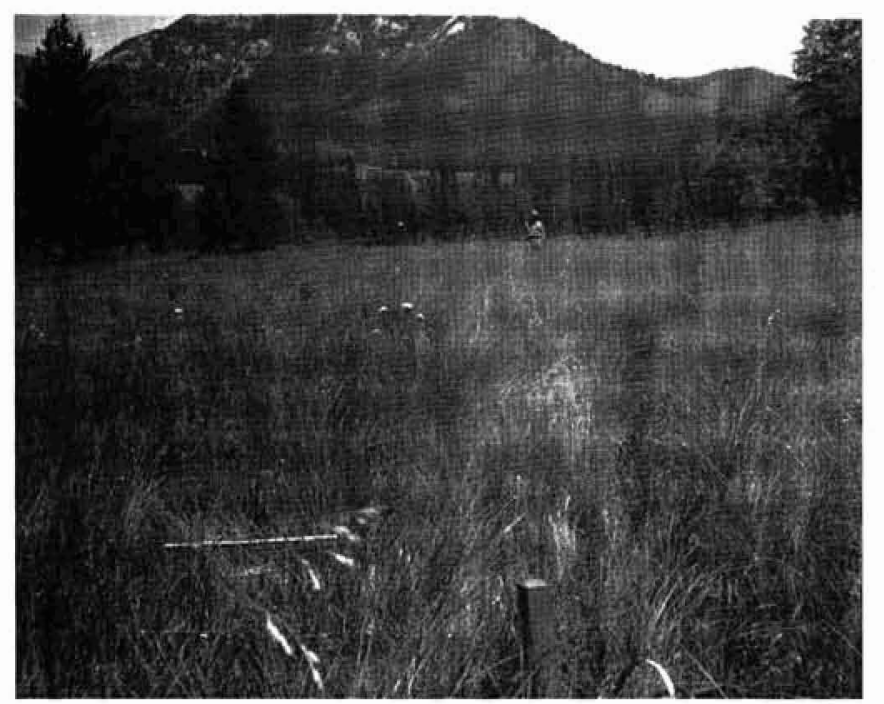

1953 $\uparrow$ $1995 \rightarrow$

In 1953 when this reference area was protected from grazing it was dominated by rough fescue. Forty years later the understory vegetation continues to be dominated by rough fescue. These rough fescue dominated grasslands represent the edaphic climax plant community in the absence of disturbance on river terraces and meadows with deep black soils in the Foothills of Southern Alberta. The lack of fire allows trees to encroach, but the time frame for complete tree invasion is unclear.
The current dilemma on which system best describes range condition has led the Task Group on Unity in Concepts and Terminology (1995) to propose that ecological site and desired plant community concepts be used to assess the status of rangelands. Ecological site is defined as "a kind of land with specific physical characteristics which differs from other kinds of land in its ability to produce distinctive kinds and amounts of vegetation and in its response to management". The undisturbed transect at the Castle reference area has succeeded to a community that is dominated by rough fescue and Kentucky bluegrass. This community type has been quite stable for the last 6 years and it seems unlikely the site will return to a community that is dominated solely by native plant species.

The desired plant community is defined as "of the several plant communities that may occupy a site, the one that has been identified through a management plan to best meet the plan's objectives for the site". Historically, the desired plant community of these rangelands was one that maximized beef production. Invaders such as timothy and Kentucky bluegrass were desirable. Today society desires the conservation of native grasslands and the desired plant community is native rough fescue. Plants considered non-native (Kentucky bluegrass, timothy and dandelion) are no longer desirable. It ap-

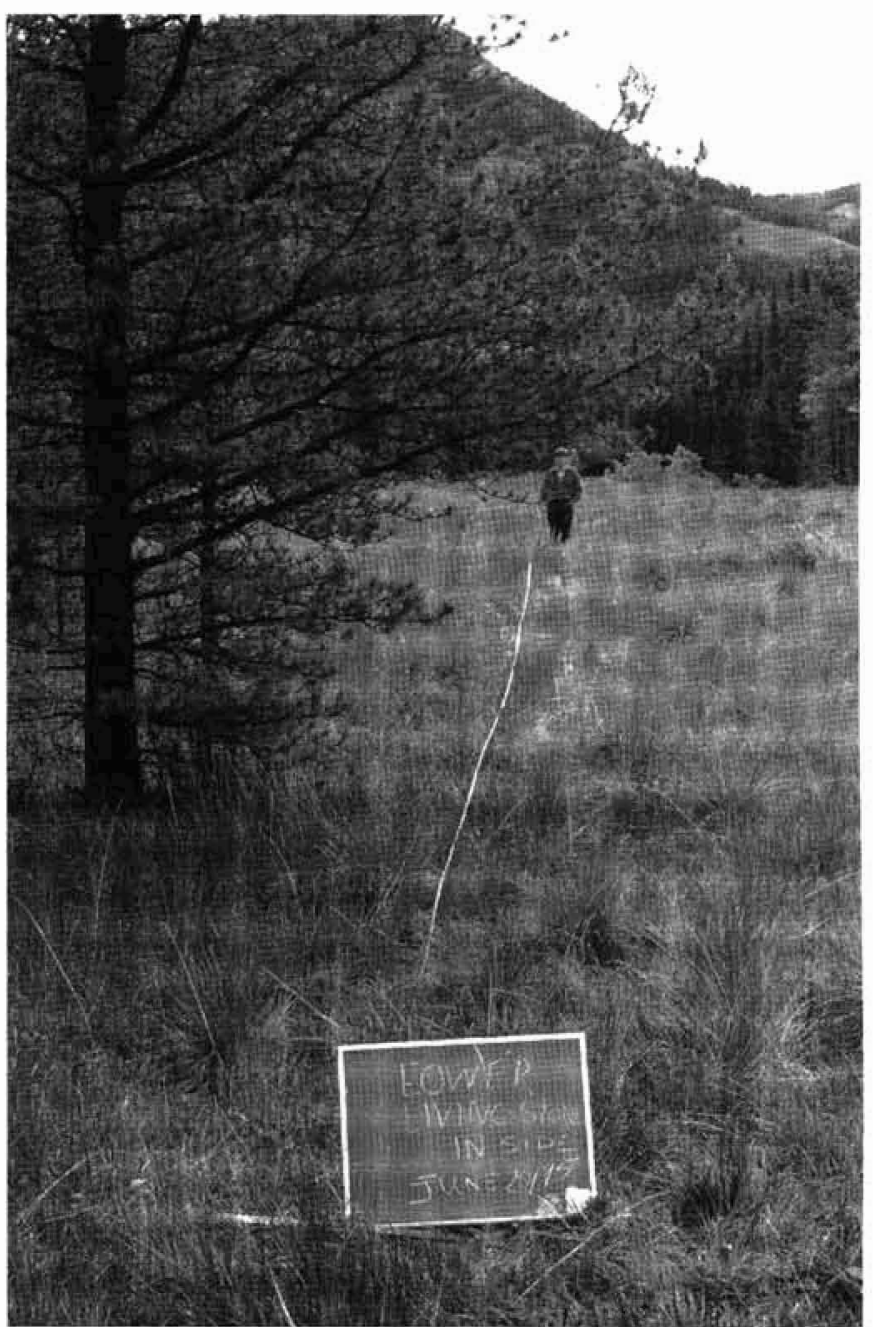


pears that the past management practices have altered the community structure so that the plant community desired by today's society is unlikely. This has created a dilemma on how range condition of these rangelands should be assessed.

New rangeland health protocols developed by the USDA are trying to address this dilemma. The USDA has created 17 rangeland health indicators to assess Soil/Site stability, Hydrologic Function and Integrity of the Biotic Community and determine if the community is stable, at risk or non-functioning and not intact (Pellant 1999). Clearly, the Castle River Rangeland Reference Area would have a stable rating for Site/Soil Stability and would be functioning hydrologically, but the Integrity of the Biotic community would not be intact. It is likely that range condition assessments will have to be done with non-native invaders as a component of the climax community, but ultimately this maybe a societal decision.

\section{Supporting Literature}

Dyksterhuis, E.J. 1949. Condition and management of rangeland based on quantitative ecology. J. Range Manage. 2:104-115.

Gauch, H.G. 1982. Multivariate analysis in community ecology. Cambridge University Press, Cambridge, 298pp.

Hanson, A.R. 1975. Current range management on forest lands in Alberta. Alberta Energy and Natural Resources, Forest Service. Unpublished report. 79pp.
Laycock, W.A. 1991. Stable states and thresholds of range condition on North American rangelands-a viewpoint. J. Range Manage. 45:427-433.

Looman, J. 1969. The fescue grasslands of Western Canada. Vegetatio, 19:28-145.

Moss, E.H. and J.A. Campbell. 1947. The fescue grassland of Alberta. Can. J. Res. 25:209-227.

Pellant, M. 1999. Presentation to RAM committee on Interagency Rangeland Health Evaluation. 1999 Society for Range Management Annual Meeting. Omaha, Nebraska. Feb 21-26.

Task Group on Unity in Concepts and Terminology. 1995. New concepts for assessment of rangeland condition. J. Range Manage. 48:271-283.

Willms, W.D., S. Smoliak and J.F. Dormaar. 1985. Effects of stocking rate on a rough fescue grassland vegetation. J. Range Manage. 38:220-225.

Willoughby, M.G. 1992. Rangeland Reference Areas: Plant communities, ecology and repsonse to grazing in Division 1. Forestry, Lands and Wildlife, Alberta Forest Service. Pub. no. T/266. 44pp.

Wroe, R.A., S. Smoliak, B.W. Adams, W.D. Willms and M.L. Anderson. 1988. Guide to Range Condition and Stocking Rates for Alberta Grasslands. Forestry, Lands and Wildlife. Edmonton. AB. 33 pp.

Authors are with the Land and Forest Service, Alberta Environment, Edmonton $\mathrm{AB}$.

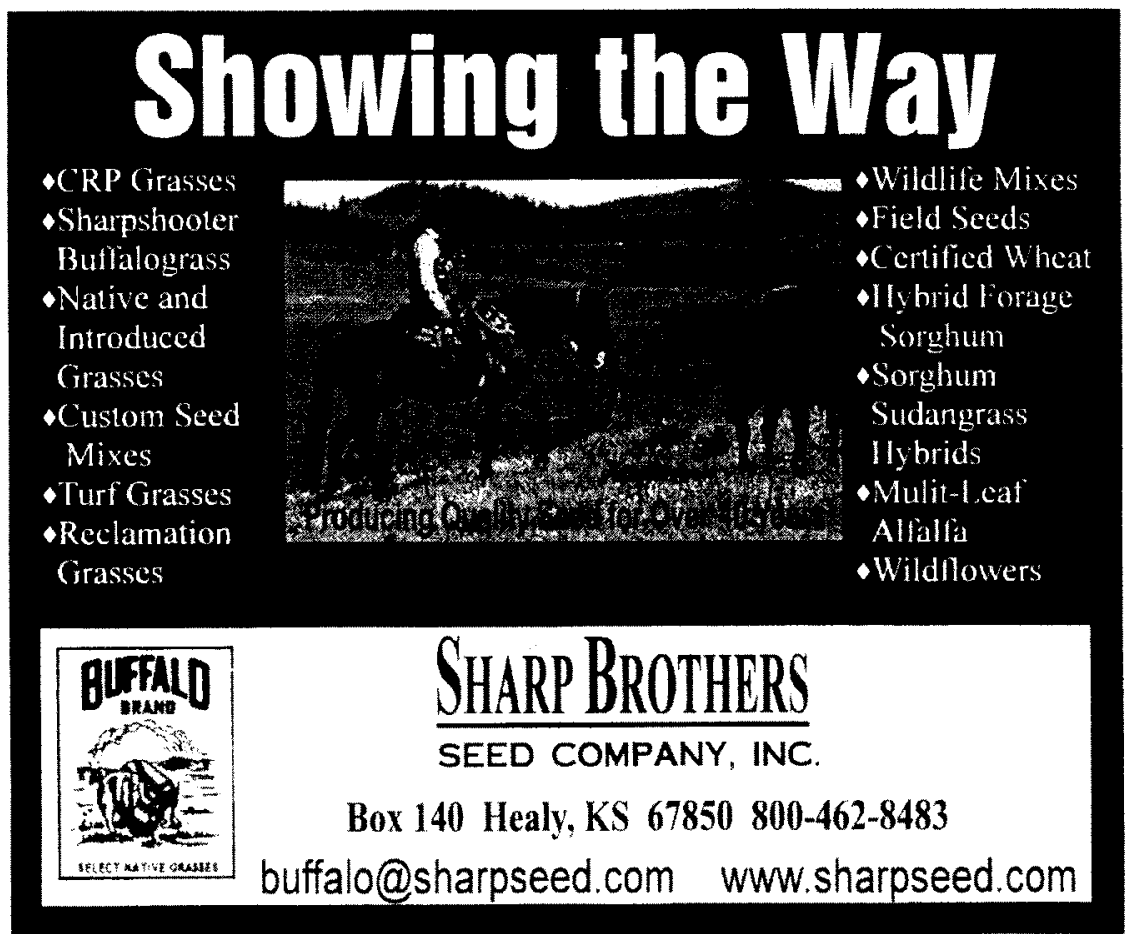

